\title{
Constructing Virtual Justice in the Global Arena
}

Ruth Buchanan

Osgoode Hall Law School of York University, rbuchanan@osgoode.yorku.ca

Source Publication:

Law and Society Review

Follow this and additional works at: https://digitalcommons.osgoode.yorku.ca/scholarly_works

Part of the Law Commons

(c) $($ i) $९ \bigodot$

This work is licensed under a Creative Commons Attribution-Noncommercial-No Derivative Works 4.0 License.

Recommended Citation

Buchanan, Ruth. "Constructing Virtual Justice in the Global Arena." Law and Society Review. 31 (1997): 363-375.

This Book Review is brought to you for free and open access by the Faculty Scholarship at Osgoode Digital Commons. It has been accepted for inclusion in Articles \& Book Chapters by an authorized administrator of Osgoode Digital Commons. 
Review Essay

Constructing Virtual Justice in the Global Arena

Ruth Buchanan

Yves Dezalay \& Bryant Garth, Dealing in Virtue: International Commercial Arbitration and the Construction of a Transnational Legal Order. Chicago: University of Chicago Press, 1996. x +343 pp. $\$ 35.00$ cloth.

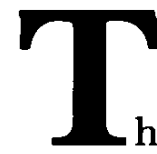

his book by Yves Dezalay and Bryant Garth, both a major empirical and theoretical contribution, has arrived at a propitious time for law and society scholars. If our discipline is not in crisis, it is certainly in a period of transition. As "globalization" has monopolized the attention of policymakers, journalists, futurists, politicians, and the business elite, scholars in law and society have not been far behind. Meetings of the Law and Society Association have become notably more international in their objects, if to a lesser extent in membership and attendance. ${ }^{1}$ As our scholarship ventures with more regularity over, under, and beyond the boundaries of nation-states, we encounter new conceptual, methodological, and practical challenges, as well as the exacerbation of some more familiar difficulties. The work of Dezalay and Garth represents one of the most advanced and concerted efforts in our discipline to rise to this array of new (and old) challenges. The book's scope and ambitions are such that a reviewer is compelled to ask whether the authors have presented us with a new paradigm for research in sociology of law in the context of globalization. As I am only presumptuous enough to pose but not to answer that question, this review essay will document both the considerable promise and some possible limita-

1 wish to thank Dave Trubek for providing feedback on an earlier draft. Address correspondence to Ruth Buchanan, Assistant Professor, Faculty of Law, University of British Columbia, 1822 East Mall, Vancouver, BC, Canada V6T 1 Z1.

1 I do not mean to suggest that there has not been significant international and comparative work done in law and society in the past; rather, recently there seems to have been a shift in both the nature and extent of this work in law and society. 
tions of the approach developed by Dezalay and Garth, in the hopes of using their work to spark a wider debate on the future of law and society scholarship in conditions of globalization.

Dealing in Virtue explicitly concerns the construction and legitimation of a realm of "private justice" for international business disputes. It is also about transformations within the legal profession in various national arenas brought about through the process of internationalization. What is important about this book is that Dezalay and Garth view these two processes as inextricably linked. They describe how segments of various nationally based legal professions both contributed to and benefited from an expanding market for international commercial arbitration, at the same time that the internal dynamics of these national professional communities were being transformed. They identify as the agents of this two-level process of transformation those individuals who were able to parlay national prestige and stature into entry to the elite "club" of international arbitrators. The emerging rules and practices of international commercial arbitration, including the doctrine of lex mercatoria, are examined as they related to the skills and experience of the arbitrators who first gained entry to the "club." Further, they describe how the appearance of a new generation of arbitrators from the United States, with different sets of skills and qualifications, corresponded with a shift toward more procedurally elaborate and factually based approaches. Dezalay and Garth have drawn on a remarkably rich body of research to narrate a convincing account of the internal dynamics of this hitherto virtually inaccessible world. ${ }^{2}$ Further, by linking competition in the market for arbitration services with substantive and procedural developments in the emerging field of international commercial arbitration, they have bridged what Bourdieu described as the arbitrary separation between the sociology of law and the sociology of the legal profession. Indeed, while Dealing in Virtue provides us with a great deal of knowledge about the world of international commercial arbitration, its authors state that its larger ambition is to see "what the study of international commercial arbitration can tell us with respect to more general theoretical questions about the role of law and lawyers" (p. 4). Following this invitation from the authors, this review first identifies a number of trajectories along which the study makes signal contributions to law and society scholarship and then open for debate two potential limitations of the approach.

First, Dealing in Virtue represents an important intervention in the recent debates concerning the globalization of law at two levels. It provides a welcome contrast to the plethora of recent

2 Almost 300 interviews were conducted with individuals from 25 countries. Most interviews were conducted in the United States or Europe, but the research included trips to sites on the "periphery" such as Cairo and Hong Kong (p. 9). 
legal scholarship on the dissemination of the rule of law, often written by the exporters themselves, which has a tendency to focus on the substantive merits of the exports rather than the process of exportation itself (Howard 1994; Sunstein 1993). Dezalay and Garth argue that it is as necessary to reveal the social contexts and corridors of transmission as it is to study the substantive provisions and ideologies being transmitted. They urge us to refocus the lens on the players, these "merchants of law," in this international marketplace of ideas to reveal how their individual backgrounds, training, career strategies, and ambitions have led them to function as agents of transmission and transformation in both national and international legal fields. Their approach also helps to reveal the export process as a two-way street, which has implications for the internal struggles ("palace wars") in the home community as well as for the receiving communities.

Their work also provides further ammunition for those who have sought to destabilize dominant assumptions concerning an overarching "logic" of globalization (Buchanan 1995; Coombe $1995 \mathrm{~b})$. Theirs is precisely the type of detailed, careful, localized investigation that social scientists seeking to understand the current transformations need to undertake. A particular strength of Dealing in Virtue is its detailed accounts of the structure and dynamics of national legal fields (France and the United States are particularly clearly drawn) and its elucidation of the particular ways in which these national fields are inscribed within the emerging international space of commercial arbitration. Their analysis suggests that what is often referred to as the "global" or "supranational" arena in law is constructed by agents operating from clearly defined national home bases, a process which has implications both for the dynamics of the national as well as the emergent international legal field. In painstakingly and insightfully piecing together these relationships, Dezalay and Garth have not only revealed the ways in which these international and national spaces are mutually implicated but also have crafted a model for thinking about current processes of globalization in terms of the evolving constitutive relationship between national/ international, or local/global, spaces.

Second, the book is a contribution to the body of sociolegal scholarship on the social construction of the legitimacy of law (Hunt 1993). Expanding on the argument introduced in their third chapter ("Merchants of Law as Moral Entrepreneurs," a revision of an article of the same title published in the Law $\mathcal{E}$ ' Society Review), the authors show how the competition for the business of business disputing has contributed to the construction and maintenance of the legitimacy of international commercial arbitration as a type of "private justice." As an emerging field of practice, international commercial arbitration gained its legitimacy and authority from the personal charisma of the notables 
who served as arbitrators after long careers in the law or public service. ${ }^{3}$ Arbitration was considered "a duty, not a career." Arbitrators were "distinguished amateurs" who could be considered independent because they did not need to rely on repeated arbitration work for their livelihoods. The expansion of demand for arbitration beyond the available supply of "grand old men" coincided with the emergence of large American law firms in Europe and efforts by these younger technocrats to break into the club previously characterizing the arbitration world. Arbitration witnessed a modified process of the routinization of charisma that transformed the way in which arbitrations were conducted but didn't fully open the closed market for arbitrators.

However, as the market expanded beyond Europe and North America, new entrants (often from countries in the South) helped to bolster the field's claims to representativeness, neutrality, and universality. The new entrants were usually those with the educational and cultural capital that enabled them to function as "double agents"-moving between their peripheral home countries and the European core. This two-way street unevenly benefits the interests of the core; "the leaders of the outpost get closer to the core, with resultant symbolic (and often material) rewards. The price they pay, however, is that they open up direct lines to the core from Cairo (or other outposts) and give up much of their distinctive identity. They do not in fact compete, but rather . . . help to complete the arbitration community" (p. 242). In Dezalay and Garth's account, the local elites are condemned to play this double game. It is only through reinforcing the legitimacy of the ideas brought by the "missionaries," helping them to gain more local recruits, that the peripheral elites will be able to maintain their own position within their communities.

The process of recentering also helped the Anglo-American law firms to make inroads under the banners of transparency, rationalization, and competition. These new entrants also attempted to transform the field in ways that would privilege their particular mix of expertise. For the Americans, this meant deploying the technologies and tactics of big litigation, including the use of multiple jurisdictions, case management skills, and arguing on the basis of facts rather than the abstract legal doctrines (such as lex mercatoria) preferred by the previous generation. In their description of the battles between the American newcomers and the European old guard, Dezalay and Garth document how competition both builds the market for a particular kind of legal service and adds to the legitimacy of the law which is produced (p. 59). They show in some detail how the various types of social

3 In describing the distinctive style of the patriarchal notables in Stockholm, the authors recount one informant's suggestion that the ideal secretary for an international arbitration would be "a man who, when he walks into a restaurant, is automatically given the best table" (p. 193). 
capital and personal charisma of elite lawyers are mobilized to legitimate an otherwise suspect kind of "offshore or private justice" designed to serve the needs of their business clients. The familiar theoretical point that is thereby underlined throughout the book is the linkage between law's claims to universality and autonomy and law's subordination to economic power.

Third, the book stands as both a contribution to and a critique of the tradition of law and society scholarship on the legal profession, although it does not explicitly identify itself as such. This is because the authors adopt Pierre Bourdieu's critique of the notion of profession as "the social product of a historical work of construction of a group and of a representation of groups that has surreptitiously slipped into the science of this very group" ( $p$. 15, citing Bourdieu \& Wacquant 1992) and, hence, avoid references to the legal profession, preferring Bourdieu's notion of the (legal) field. The research can be read as an extension of and expansion on much of Dezalay's earlier work (1990; Dezalay et al. 1994) on the transformation of the structure of the practice of law and the legal profession in Europe, particularly in France, through competitive battles with big American law firms that came on the scene in the 1970s. The rise of the market for international arbitration appears to correspond temporally with the emergence of American firms in the European market, and some of the key struggles Dezalay and Garth use to illuminate the arbitration story will be familiar to readers of Dezalay's earlier work; the intergenerational conflict between "grand old men" and young "technocrats," for example, as well as the parallel conflict between academics and practitioners.

Dezalay and Garth have drawn the notion of the "field" as well as much of the theoretical and methodological ideas that inform their approach from the work of Pierre Bourdieu, who has contributed a Foreword to the volume. Like Bourdieu, the authors avoid much overt "theorizing," preferring to allow the method to reveal itself through the narrative as it unfolds. Nonetheless, they do spend some time explaining the research "strategy" early in the volume for readers who may be unfamiliar with Bourdieu's approach, observing as they do so that "Bourdieu's work [has been] used mainly as a kind of ornamental reference by most "law and society" or "neoinstitutionalist" scholars. The structural and reflexive parts of the approach are forced into, or put aside in favor of, a more "scientistic" and positivistic framework" (p. 4). The elaboration and legitimation of Bourdieu's approach into the field of sociology of law might be described as the fourth, and largest, ambition of the book.

Although an examination of Bourdieu's sociology and some of the extant critiques of it may be somewhat too ambitious for a review essay, it seems appropriate to attempt a brief foray into this terrain as the approach does indeed have much to offer to 
law and society scholars, and it has not yet been well explored within the law and society community. ${ }^{4}$ Bourdieu's notions of the field and symbolic capital are powerful tools that enable researchers to investigate social phenomena in a more dynamic and integrative way than other available approaches. First, the notion of the field enables the researcher to allow the object of research to constitute itself through the ongoing processes of conflict and competition, as well as those of cooperation and cooptation, that are at the center of social life, rather than imposing a structure on a given area of inquiry from the outside. As Shamir (1995:6) puts it, "The field . . . both constrains and enables action. It is shaped by actors and at the same time gives shape and meaning to the various discursive and nondiscursive practices that are realized within it." It is the field as a theoretical starting point that enables Dezalay and Garth to get beyond the separation between the practice of international commercial arbitration and the social backgrounds and career trajectories of those who pioneered it.

Second, the notion of symbolic capital mediates between the economic or material and the symbolic or ideological realms; it allows research to move beyond these dichotomies. The notion of symbolic capital is what enables Dezalay and Garth to reveal the connections between the ongoing construction of the legitimacy of international commercial arbitration and the social (and economic) power attached to the agents of that construction. They make the general observation that "recognized high status within the legal field is given to those who help to build the universality that is essential to the legitimacy of law" (p. 19). The elaboration and application of the notions of the field and of symbolic capital to the domain of law more generally are major contributions of the book, and should prompt a more wide-ranging debate on the utility of Bourdieu's approach for the sociology of law.

Perhaps Bourdieu's most central concern, conditioned by his own coming of age in the French intellectual field dominated by the opposition between Sartre's voluntarism and Lévi-Strauss's structuralism, is to mediate between what he sees as the "false dichotomy" of subjectivism and objectivism. Bourdieu thinks that each of these approaches to the study of social life, taken on its own, is unsatisfactory. On the one hand, the objectivist point of view has a tendency to "reify the structures it constructs by treating them as autonomous entities endowed with the ability to 'act' in the manner of historical agents" (Bourdieu \& Wacquant 1992:8). For the objectivist, practice can only be understood as the mechanical working out of the logic of the structures seen only from the outside. For Bourdieu, the limited nature of this

4 An exception is the work of Ronen Shamir (1995). 
external approach dictates that the process of social theorizing must also integrate the agent's own understandings of the social world. ${ }^{5}$ While giving recognition to the work of world-building encompassed in ongoing acts of representation by social actors, Bourdieu also warns against the limitations of a purely phenomenological approaches in failing to provide any insights into the larger patterns or processes of social reproduction. The real challenge for social research is to overcome the false dichotomy that has set these modes of knowledge against one another in order to be able to incorporate both perspectives without jettisoning their distinctive insights (Bourdieu 1988).

Bourdieu describes his own approach both as a "structuralist constructivism" and a "constructivist structuralism" to emphasis the "double reading" that is required to accomplish this goal (Bourdieu \& Wacquant 1992). However, if the two moments are both necessary, they are not equal. For Bourdieu (1984:728), the (objective) structures of social space always underpin and give shape to the representations and possibilities perceived by social actors:

The categories of perception of the social world are, as regards their most essential features, the product of the internalization, the incorporation, of the objective structures of social space. Consequently, they incline agents to accept the social world as it is, to take it for granted, rather than to rebel against it, to counterpose to it different, even antagonistic, possibilities.

Bourdieu's structuralism is one that "both allows space for and accounts for agency" but only within the context of his notion of "habitus," the dispositions or embodied categories of perception through which agents make sense of and act in the world. The fact that the habitus is defined by an individual's social class or location, even where the notion of class is highly nuanced and culturally mediated, raises concerns about the degree of social determinism of the account (Harker 1990). Second, the focus on mechanisms of social reproduction tends to give rise to a corresponding pessimism regarding the possibility of social transformation that troubles some sympathetic critics (Lash 1993).

To the extent that Dezalay and Garth have endeavored to apply Bourdieu's structural method to the field of law, their account may well be subject to some of the same concerns. As I have already noted, they have adopted Bourdieu's notion of both the field and symbolic capital in order to locate the individuals they interviewed within the structured field of competition for the business of international commercial arbitration. Although

5 Bourdieu (1984) further writes: "The most resolutely objectivist theory has to integrate the agents' representation of the social world; more precisely, it must take account of the contribution that agents make towards constructing this world, by means of the work of representation (in all senses of the word) that they constantly perform in order to impose their view of the world or the view of their own position in this world-their social identity." 
their descriptive chapters are replete with the words of their interview subjects, they don't use the notion of "habitus" or a corresponding reference to the need to incorporate the understandings of their subjects into the structure of their account. Although Dezalay and Garth are careful to advise us that their "theoretical chapters are not written to be the last word, the final truth that emerges out of descriptive chapters organized and written to underscore the validity of the last word" (p. 14), there is a revealing contrast between the complexity that emerges in the chapters which draw on more of the interview data and the relative clarity and conceptual elegance of the more theoretical chapters. One could suggest, however, that this is no more than the creative tension one finds in all good social science between empirical complexity and narrative simplicity.

Why, then, do I consider this contrast a potential difficulty for Dezalay and Garth's approach? It has to do with the economic heuristic embedded in the account. Bourdieu's notion of "symbolic capital" functions to extend the scope of the operation of self-interested activity into the cultural and symbolic spheres, including law (McCall 1992). This economic logic, in Dezalay and Garth's account, is not mediated by any theoretical account of individualized dispositions or possible choices. It becomes difficult to imagine how the representations or actions of individuals within this model might be explained other than in terms of self-interested maximization of their position within the field. While this may pose less of a problem when the subjects one is studying are commercial arbitrators, it might be a possible limitation when the focus of study shifts to human rights lawyers or environmental activists.

While the empirical richness of their book seems to belie this tendency, Dezalay and Garth appear to have come down rather firmly on the structural side of Bourdieu's sociology. This also lends their account the same conservative bias with respect to the relationship between the legal field and social change. While they identify and explain the dynamics of intergenerational rotations, they suggest that a "social logic" of the field remains intact through these transformations:

The field represents a space of positions and struggles that produce, render obsolete, or reinvent social institutions. The field may certainly be transformed, but in the absence of major unsettling events like wars or political upheavals, the change takes place according to a social logic and even a rhythm of generations. (P. 316)

Although Dezalay and Garth, like Bourdieu, begin with individuals and social groups rather than institutions (p. 16), their analysis tends to privilege the examination of continuities over discontinuities, social reproduction over social change. While in some contexts and for some purposes, this type of an approach is par- 
ticularly valuable, in the context of the transition now occurring in many parts of the global economy from Fordist to post-Fordist forms of social and economic regulation, it is arguably less so. In these times of rapid change, crisis, and uncertainty, it becomes particularly important to develop theories and methodologies for social research that are attentive to disruptions and changes rather than continuities and stabilities (Lash \& Urry 1994; Amin 1994).

Dezalay and Garth are not alone in seeking to explore Bourdieu's approaches within the legal field. Other scholars within the law and society community have appropriated aspects of Bourdieu's theory of practice quite differently. Practice theory, for some, presents an opportunity to reveal the creativity and agency of everyday life or to highlight the struggles over classification and exclusion that form the core of the most seemingly stable social formations (Coombe 1989; Trubek 1990; Buchanan 1994). In contrast to the bias toward revealing the mechanisms of social reproduction evident in both Bourdieu's own work and that of Dezalay and Garth, these critical appropriations seek to turn the study of practice toward the exploration of possibilities for social ruptures, destabilizations, and discontinuities. For example, although the conception of gender is one that is not systematically incorporated into the accounts of social fields offered by Bourdieu (or by Dezalay and Garth), feminists have suggested that the approach offers a number of tools that are consonant with, and applicable to, evolving feminist methods and approaches to social research (McCall 1992; Krais 1993; Coombe 1989).

While feminist analysis is, like that of Bourdieu, poised between an appreciation of (gendered) social structures and the ongoing creative agency of everyday life, feminist analysis inclines toward rupture rather than closure, social change rather than reproduction. For women, often, the "fit" Bourdieu posits between positions and dispositions, between habitus and field, breaks down. Women find themselves reflecting, "But that's not me" (McCall 1992:850). Feminist approaches (along with many other types of critical theory) are not satisfied with an account of the social world that merely reveals structures of domination; they must incorporate a consideration of how those structures might be changed. Central to that analysis is the examination of the role of the social scientists themselves, which is another moment of convergence between feminist theory and Bourdieu. Feminist critical epistemologies and standpoint theories emerged out of the understanding that the field of social inquiry is an arena of knowledge production where meaning is contested and constructed and from which women and women's contributions have been historically marginalized and excluded (Haraway 1988; Harding 1987). This reversal of the lens of inquiry back on 
the producers of knowledge has parallels in the reflexivity of Bourdieu's sociology, which can be described as "not simply telling the truth of this world, as can be uncovered by objective methods of observation, but also showing that this world is the site of ongoing struggle to tell the truth of this world" (McCall 1992:855, quoting Bourdieu from Wacquant 1989:21). Both identify these struggles, although they may be acted out in the guise of debates over epistemology, as essentially social and political. Both agree that what (and who) counts-as research subjects, as legitimate methodology, as authorities or experts-is a political question. Where the approaches diverge is over what the social scientist can or must do in practice with that insight. For feminists, helping individuals to "see that the hierarchies and categories that make acquiescence to economic and political power seem natural and inevitable are themselves the product of struggles” (p. 317) is the beginning, rather than the end, of the theoretical project.

Perhaps it is this divergence that underlay my own occasional sense of discomfort on reading Dealing in Virtue, notwithstanding what I have acknowledged as the very significant accomplishments of the book. Despite its relentless focus on the social backgrounds of individuals and the scrutiny of the myriad ways in which what counted as social and symbolic capital was parlayed into personal and professional advancement at the intersection of the national and the international, the book contains very little in the way of this type of reflexive inquiry. I often found myself thinking of the authors themselves and how it was possible for them undertake such a daunting research exercise, to gain access to these very tight social networks in such a range of geographically disparate locations. How did they relate to the community of arbitrators, and what was the response to the book within that community? What about the book's impact on the dynamics of our own small field of social scientists who study law and the even smaller (but growing) group who purport to extend the ambit of that research into the international arena?

In the same way that Dezalay and Garth show how internationalization functions to exacerbate existing divisions within national legal fields, I wonder whether the recent shift of attention toward globalization within the law and society community will result in the reinforcement of similar hierarchies. Their book presents us with an opportunity to reflect on the shifting intellectual currents within our own communities and the power relations implicated within them. Will research on globalization carry its own cachet that enhances the careers of those who are able to marshall the resources to carry it out? Will a paradigm for research in the context of globalization emerge? Or will this small field become as plural and diverse in its methods and approaches as the remainder of the law and society community? I 
am concerned about the implications of the convergence of these two tendencies: an implicit privileging of the global (or international) as a site for research, and the engagement of a relatively limited number of scholars, and consequently disciplines and methods, in the work.

These concerns converge with some expressed in a recent debate in the pages of the Law $\mathcal{E}^{\circ}$ Society Review where we were called on to reimagine our work in ways that move us past the "paradigmatic crisis" of modern science and, in so doing, acknowledge our complicity with the imperialist forms of law (Santos 1995; Law \& Society Review 1995). As John Brigham (1995) points out in his contribution to that debate, acknowledging complicity, "going South," is not simply a matter of changing the objects of our inquiry but must be reflected in our practices as an association. As the research of the Law and Society Association expands beyond the boundaries of the United States and Western Europe, our methods and our membership must strive to become more rigorously diverse and heterogeneous. We need to be more attentive to the ways in which our methods and approaches can serve to reinforce and reproduce the patriarchal and imperialist relations we purport to be merely studying.

Paraphrasing Rosemary Coombe's contribution to the recent symposium, I would suggest that one way to do this as social science researchers is to put ourselves at risk by continuously interrogating our own privileges (Coombe 1995a). This is why, in praising the scope and accomplishment of Dezalay and Garth's research, I have also reflected on the privileges that informed and underlay its production. One of those privileges is precisely the ability to take a stance toward research that does not prioritize the task of facilitating social change. Also, while praising the authors' methodological achievements in extending Bourdieu's concepts and insights into the national and international legal field, I must also reflect on the enthusiasm with which they undertake that project. To return to my initial provocation, the insights offered by Dezalay and Garth's book will be most useful to law and society scholars not as a new paradigm but as a set of appropriations. We shouldn't be as worried about "getting it right" as we are about putting it to work. Dealing in Virtue stands as a significant contribution to our understanding of the relationship between law, lawyers, and increasingly globalized economic power as well as to our methodological tool kits. It can also provide an opportunity for law and society scholars to reflect on the impact of globalization on the direction of change within our own community and in how we, as social scientists doing work on law, are implicated in the ongoing construction of justice and injustice in the global arena. 


\section{References}

Amin, Ash, ed. (1994) Post-Fordism. Cambridge, MA: Blackwell.

Bourdieu, Pierre (1984) "Social Space and the Genesis of Groups," 14 Theory $\mathcal{E}$ " Society 723-44.

- (1988) "Vive la Crise! For Heterodoxy in Social Science," 17 Theory EF Society 773-89.

Bourdieu, Pierre, \& Loic Wacquant (1992) An Invitation to Reflexive Socialogy. Chicago: Univ. of Chicago Press.

Brubaker, Rogers (1985) "Rethinking Classical Theory: The Sociological Vision of Pierre Bourdieu," 14 Theory E $\mathcal{E}^{2}$ Society 745-75.

Brigham, John (1995) "The Challenge of the South," 29 Law E Society Rev. 585-91.

Buchanan, Ruth (1994) "Context, Continuity and Difference in Poverty Law Scholarship," 48 Miami Law Rev. 999-1062.

__ (1995) "Border Crossings: NAFTA, Regulatory Restructuring and the Politics of Place," 2 Indiana J. of Global Legal Studies 371-93.

Calhoun, Craig, Edward LiPuma, \& Moishe Postone, eds. (1993) Bourdieu: Critical Perspectives. Chicago: Univ. of Chicago Press.

Coombe, Rosemary (1989) "Room for Maneouver: Toward a Theory of Practice in Critical Legal Studies," 14 Law E Social Inquiry 69-121.

___ (1995a) "Finding and Losing One's Self in the Topoi: Placing and Displacing the Postmodern Subject in Law," 29 Law E' Society Review 599-608.

- (1995b) "The Cultural Life of Things: Anthropological Approaches to Law and Society in Conditions of Globalization," 10 American Univ. J. of International Law EO Policy 791-835.

Dezalay, Yves (1990) “The Big Bang and the Law: The Internationalization of the Legal Field," 7 Theory, Culture EF Society 279-93.

Dezalay, Yves, with David Trubek, Ruth Buchanan, \& John Davis (1994) "Global Restructuring and the Law: Studies of the Internationalization of Legal Fields and the Creation of Transnational Arenas," 1994 Case Western Law Rev. 407-98.

Haraway, Donna (1988) "Situated Knowledges: The Science Question in Feminism as a Site of Discourse on the Privilege of Partial Perspective," 14 (3) Feminist Studies 575-99.

Harding, Sandra (1987) The Science Question in Feminism. Ithaca, NY: Cornell Univ. Press.

Harker, Richard, ed. (1990) An Introduction to the Work of Pierre Bourdieu: The Practice of Theory. New York: Macmillan.

Howard, A. E. Dick (1994) "Constitution Making in Central and Eastern Europe," 78 Suffolk Univ. Law Rev. 5-16.

Hunt, Alan (1993) Explorations in Law and Society: Toward a Constitutive Theory of Law. New York: Routledge.

Krais, Beate (1993) "Gender and Symbolic Violence: Female Oppression in the Light of Pierre Bourdieu's Theory of Social Practice," in Calhoun et al. 1993.

Lash, Scott (1993) "Pierre Bourdieu: Cultural Economy and Social Change," in Calhoun et al. 1993.

Lash, Scott, \& John Urry (1994) Economies of Signs and Space. London: Sage Publications.

Law \& Society Review (1995) "Charting a Course for Sociolegal Scholarship: A Symposium," 29 Law E Society Rev. 567-638.

McCall, Leslie (1992) "Does Gender Fit? Bourdieu, Feminism and Conceptions of Social Order" 21 Theory E Society 837-67.

Santos, Boaventura de Sousa (1995) "Three Metaphors for a New Conception of Law: The Frontier, the Baroque and the South," 29 Law E Society Rev. $569-84$. 
Shamir, Ronen (1995) Managing Legal Uncertainty: Elite Lawyers in the New Deal. Durham, NC: Duke Univ. Press.

Sunstein, Cass R. (1993) "On Property and Constitutionalism," 14 Cardozo Law Rev. 907-35.

Trubek, David M. (1990) "Back to the Future: The Short, Happy Life of the Law and Society Movement," 18 Florida State Univ. Law Rev. 1-54.

Wacquant, Loic (1989) "Toward a Reflexive Sociology: A Workshop with Pierre Bourdieu" (interview with Loic Wacquant), 7 (1) Sociological Theory 26-63. 
